\title{
Education for entrepreneurship: In search of the fifth pillar "Learning to be entrepreneurial"
}

\section{Educación para el emprendimiento: en busca del quinto pilar "Aprender a ser emprendedor"}

Received: March 12, 202

\begin{abstract}
Currently, the entrepreneurship boom is on the rise, education centers from elementary to higher education are betting on providing an entrepreneurial education. The purpose of this article is: To recognize the development of social entrepreneurship competencies from the four pillars of education, adding a fifth pillar which "knows how to be an entrepreneur". In addition, it is achieved: to recognize the transforming mission of social entrepreneurship competencies within the educational field, to identify the challenges faced by educational systems and how school entrepreneurship is adapted, to compare successful experiences of different countries in entrepreneurship, to analyze the importance of entrepreneurial education from the four pillars as a basis for the construction of the fifth pillar "Learning to undertake" and to differentiate the roles of the educational community. Consequently, documentary analysis is used, after selecting articles, various books, congresses, etc. related to educational entrepreneurship.
\end{abstract}

Accepted: June 12, 2021

\author{
Written by: \\ Alejandro Cruzata-Martínez ${ }^{29}$ \\ https://orcid.org/0000-0003-0104-0496 \\ Henry Arturo Quijano Benavides ${ }^{30}$ \\ https://orcid.org/0000-0001-9897-5145 \\ Luz Elizabeth Vergaray Charra ${ }^{31}$ \\ https://orcid.org/0000-0002-5073-653X \\ Ronald M. Hernández ${ }^{32}$ \\ https://orcid.org/0000-0003-1263-2454 \\ Miguel A. Saavedra-López ${ }^{33}$ \\ https://orcid.org/0000-0003-4913-933X
}

\footnotetext{
${ }^{29}$ Universidad San Ignacio de Loyola, Lima, Perú.

${ }^{30}$ Universidad San Ignacio de Loyola, Lima, Perú.

${ }^{31}$ Universidad San Ignacio de Loyola, Lima, Perú.

32 Unidad de Virtualización Académica, Universidad de San Martin de Porres Perú.

${ }^{33}$ Facultad de Humanidades, Universidad Continental, Cusco, Perú.
}

Actualmente, el boom del emprendimiento va en aumento, los centros educativos desde la educación básica hasta la superior están apostando por brindar una educación emprendedora. El propósito de este artículo es: Reconocer el desarrollo de las competencias del emprendimiento social desde los cuatro pilares de la educación, agregando un quinto pilar el cual “saber ser emprendedor". Además, se logra: reconocer la misión transformadora de la sociedad competencias de emprendimiento dentro del ámbito educativo, identificar los desafíos que enfrentan los sistemas educativos y cómo se adapta el emprendimiento escolar, comparar experiencias exitosas de diferentes países en emprendimiento, analizar la importancia de la educación emprendedora desde los cuatro pilares como base para la construcción del quinto pilar "Aprender a emprender" y diferenciar los roles de la comunidad educativa, por lo que se utiliza el análisis documental, previa selección de artículos, libros diversos, congresos, etc. relacionados con el emprendimiento educativo. 
Keywords: Pillars of education, learning entrepreneurship and social entrepreneurship competencies.

\section{Introduction}

Today's world is undergoing constant transformations that generate not only progress but also uncertainty in the economic field. For this reason, it is essential to promote and develop skills that lead to effectively cope with current challenges. In this sense, the promotion, acquisition and development of entrepreneurial skills should be considered within the educational curriculum.

From there, different world organizations suggest that educational institutions take on education in entrepreneurship, with the intention that students can act responsibly, anticipating the challenges and economic needs.

In this regard, Lederman, Messina, Pienknagura \& Rigolini (2014), mention that the World Bank recognizes that entrepreneurs play a very important role in the development of society, capable of transforming ideas into initiatives, with the ability to innovate and lead other people. However, in order for entrepreneurs to prosper successfully, a favorable economic and political environment is required to encourage the growth of innovation.

For their part, Seria, et al., (2020), note that for the Global Entrepreneurship Monitor (GEM), public policy makers and academics agree that entrepreneurship has a major importance in social progress. Thus, it creates jobs, boosts investment and strengthens a country's economy through the development of competencies that contribute to productivity and competitiveness.

Therefore, for UNESCO (2016), education is at the core of the 2030 agenda, within the "Sustainable Development Goal" (SDG) number 4 , and the efficiency of the educational service must be certified. To achieve this, entrepreneurship is included in goal 4.4, which proposes to increase the number of students with the necessary knowledge, skills and competencies to ensure a decent job and life.

For this reason, Hidalgo (2000), shares the report made by the international commission headed by the renowned intellectual Jacques Delors, requested by UNESCO, which proposes four essential learning processes: The first "Learning to know", which seeks to deepen knowledge. The second "Learning to do" highlights the ability to cope with different situations and to work in
Palabras clave: Pilares de la educación, el aprendizaje del emprendimiento y competencias del emprendimiento social.

teams. The third "Learning to live together" mentions the importance of understanding the other, carrying out projects together and finally the fourth "Learning to be" concerning the ability to work autonomously and personal responsibility.

Therefore, education must be conceived as a whole and to achieve this Mayor (1998), adds a fifth pillar called: "Learning to undertake", being a cornerstone for the construction of the tomorrow we long for.

Likewise, "The Organization for Economic Cooperation and Development" OECD (2016; 2019), recognizes that education leads to economic growth, social inclusion and equality. At the same time, it addresses issues such as the quality of education systems, with the aim of preparing citizens with the ability to meet the challenges of the modern world.

On the other hand, the Global Entrepreneurship Monitor (GEM) was created in 1997 and is considered today the largest global project in charge of entrepreneurial research. For this reason, Peru has been part of this initiative since 2004, together with 54 countries from the five continents (Langevang, et al., 2015; Ministry of Education, 2017; National Council of Education, 2020)

For the (GEM) according to the experts' assessment, Peru's results in terms of entrepreneurial activity compared to 54 countries are as follows: Referring to the self-perception towards entrepreneurship is located in position four below Saudi Arabia, Angola and Sudan, in relation to the motivation index for entrepreneurship in position 23 , at the level of nascent entrepreneurs position 2, at the level of new entrepreneurs position 19 and at the level of entrepreneurial activity in the early stage position 5 (Langevang, et al., 2015)

Despite the high innovative spirit of Peruvians, in recent years there has been a high mortality rate in entrepreneurial activity, 6.2\% compared to $5.2 \%$ in the region. Consequently, this reality requires us to reinforce the entrepreneurial spirit from the basic educational levels, leading them to enhance their entrepreneurial skills that lead to innovative outlets that are sustained over time. 


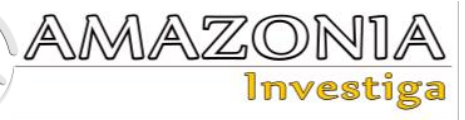

In addition to this, the National Educational Project PEN to 2036, within the fourth purpose linked to productivity, states the importance of educating students integrally from early childhood, with the intention that they can realize their life project. Likewise, to prepare them to perform productively, taking advantage of cultural, natural and economic resources in a creative, responsible and sustainable manner.

Therefore, the school curriculum outlines the achievement of the competence that seeks students to manage entrepreneurial projects from the classroom. Hence, they can put into action an innovative idea, using available resources with the intention of solving economic, social and environmental problems (Cabana-Villca, et al., 2013).

Consequently, after an exhaustive analysis of national and international surveys, the experts conclude that it is urgent to improve and strengthen state policies that promote entrepreneurship and optimize business competence. In addition, they propose to the government to support entrepreneurs during the first years of growth of their companies, where there is a greater probability of failure, adapting and making tax and labor regulations more flexible.

For a better understanding, we pose the following guiding questions: How do social entrepreneurship competencies fulfill their transformative mission, how to propose an entrepreneurial education from the four pillars, what are the roles of the educational community in learning to be an entrepreneur, how to build the fifth pillar "learning to be an entrepreneur", and what are the challenges of educational systems to implement and adapt entrepreneurship education to different contexts, which will be analyzed during the presentation of this paper.

When analyzing the favorable conditions for entrepreneurship to take place, the experts of the global monitoring of entrepreneurship within the world education policy suggest integrating entrepreneurship as a cross-cutting competency within the educational curriculum. At the same time, they recommend training the entrepreneurial spirit, creativity and innovation throughout the educational system, providing a methodology that leads to the development of social entrepreneurship competencies, facilitating tools and resources from their environment that promote education for entrepreneurship.

\section{Results and discussion}

1. The path of education for entrepreneurship from the four pillars.

When talking about entrepreneurship, Bula (2012) indicates that we can find multiple aspects in its conception. Understanding that entrepreneurship will take place within the social and cultural relationship that is directed towards the transformation of ideas into actions (Shapero \& Sokel, 1982).

For Timmons (1989), he mentions that entrepreneurship seeks to create and build on something that is of great utility. Above all, it provides the ability to face the risk of failure. Likewise, Schumpeter (1934), emphasizes that entrepreneurship from the economic point of view is a set of innovative actions that create new products and processes that allow opening the way to new markets, discovering new services and establishing new socioeconomic dynamics. With regard to competencies, Crisólogo (2008) understands them as a set of complex capabilities, i.e. know-how. They allow acting effectively in different problematic situations for the resolution of any real situation.

On the other hand, Tobón (2010) emphasizes that competencies should be treated from a transdisciplinary perspective, being a flexible and integrative model, since it requires the approach and contribution of different disciplines in order to understand the dimensions of human performance.

Likewise, competencies are assumed as a process of continuous improvement, based on the contribution of different sciences such as philosophy, sociology, linguistics, psychology, etc. What is more, its academic application at educational levels began in the 1990s and already in 2000 it became part of an educational policy of global importance.

Similarly, López (2016), validates that competencies are integrated, being able to articulate, synthesizing and combining knowledge, allowing knowing how to act in the exercise of a profession, as well as developing academic activities.

On the other hand, it enables the identification, interpretation and resolution of problems, updating knowledge to apply them and achieve the objectives, according to personal and group requirements. 
Regarding social entrepreneurial competencies, Sáenz \& López (2015), describe that a social entrepreneur has the mission to provide answers, being an agent of change with social values, capable of identifying opportunities for the common service. Likewise, he/she is innovative, adaptable, learns and acts despite limited resources. He is highly responsible and puts his personal interest aside for the good of the community.

In relation to this, when referring to a competency, it is observed that it can be learned and improved. Therefore, when undertaking social entrepreneurship within the educational environment, the promotion of development in creative, imaginative, critical, collaborative and proactive aspects is prioritized. (Sáenz \& López, 2015; Sánchez, 2013; Taatila, 2010; Arruti \& Castro, 2019).

This is how Martínez \& Carmona (2009), define entrepreneurial competence as a generator of economic growth projects and integrated social development. It favors the entrepreneurial initiative and the vision of competences. It also allows people to be able to face their personal dimensions, such as autonomy and selfregulation. Social, social and environmental responsibility. And economic, related to business projects.

On the other hand, Sáenz \& López (2015), classify social entrepreneurship competencies in four blocks, the first related to the tasks or work to be performed. The second is related to the integration of peers. The third is related to the development of people's capabilities. And finally, philosophical and ethical competencies. Within the first block are innovation and creativity, since they allow the implementation of new ideas, having a vision with future projection, giving rise to establish opportunities for entrepreneurship. This is how clear goals are set, making appropriate and effective decisions. On the other hand, planning and management ensure organizational capacity, providing creative solutions to problems. It is important to take into account time management, since it distributes time correctly, maximizing results.

In the second block we identify leadership as influencing others, having an effective relationship that leads to teamwork, integrating and collaborating actively. In addition to this, effective communication favors effective listening, as well as motivation allows the development of interest in the work.
The third block recognizes initiative and proactivity to anticipate the future. Autonomy fights for independence and liberation, adapting and flexibilizing towards new challenges. Thus, tenacity and perseverance will allow overcoming adversities, having the ability to overcome failure. On the other hand, confidence and intrinsic motivation will allow self-esteem. By mastering stress and tolerating uncertainty, tensions and insecurities are controlled. Having the ability to assume responsibilities.

The fourth and last block highlights the code and ethical feeling of the fundamental rules on the protection of their fellow men and the preservation of nature. The reflection of the good towards others. As well as acting according to current needs on critical thinking, questioning capacity and the maintenance of values. The implication of the social reality with the commitment to common development is also highlighted.

In conclusion, the competencies of social entrepreneurship break the traditional teaching scheme by developing in students a vision of the future, leading them to transformation and progress in their living conditions.

From 4 pillars the education into the competencies of social entrepreneurship.

In order to analyze and propose entrepreneurial development in primary level children, it is required to transform ideas into actions that build attitudes and skills to encourage entrepreneurship, based on social and environmental issues, involving all actors in the educational process (Gómez, et al., 2017).

Entrepreneurship education should provide the tools that promote entrepreneurship. Which provide solutions to possible problems of context and thus lead to future initiatives, being fundamental the formation of a cognitive structure and processes of social interaction thanks to the real and complex situations that are involved.

Various approaches and contexts attempt to operationalize entrepreneurial competencies, alluding to the attitudes, knowledge and skills of people who seek to transform their living conditions. Thus, it is important to understand the criteria that imply a competency. However, the knowledge of an entrepreneurial competency has not yet been identified, so that, depending on the context, some knowledge will be required. 


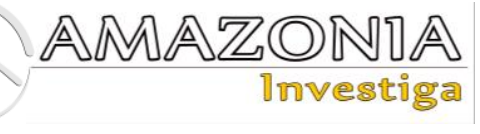

A first approach is related to knowing how to be, for which we seek to develop proactivity, creativity, self-efficacy, self-confidence, being able to take risks, having self-awareness, being sufficiently tolerant to ambiguity and frustration, as well as always being persevering.

A second approach has to do with knowledge related to the labor world and its socioeconomic movements. At the same time, the management of economic and financial aspects, the application of business processes, recognition of laws in favor of citizens. As well as, diverse tools that allows the evaluation of the opportunity and finally the development of the entrepreneurial role.

Finally, a third approach refers to know-how, in which it is demonstrated that it is possible to solve problems, exploring new opportunities, establishing effective communication and teamwork.

All entrepreneurial educational development is focused on developing theoretical and conceptual content in order to create companies, prioritizing technical and financial content, as well as organizational, production and marketing. However, from education, the aim is for people to be entrepreneurs from their personal lives, to understand the social dynamism, being visionaries and leaders.

2. How to approach the fifth pillar "learning to be an entrepreneur" from the educational field

At the beginning, entrepreneurship was purely in the economic field, but over the years it has been extended to the educational scenario. Thus, since 1970, entrepreneurship has been included in the curriculum design of higher education in careers related to administration.

Likewise, within formal education, entrepreneurship is addressed through three approaches; the first one proposes an "education in entrepreneurship" whose function is to provide students with the theoretical and conceptual support, guiding them to the creation of their own companies, empowering them with financial knowledge in the productive field. The second one deals with entrepreneurship education, whose main objective is to provide a set of knowledge and skills that clarify how to become an entrepreneur. Finally, "education for entrepreneurship" is proposed, which develops, improves and expands the first two, enhancing the disposition of the person from their personal reality, strengthening their capacities, attitudes and entrepreneurial skills, which will be valuable to face challenges in the different scenarios where they develop, (Gómez, et al., 2017; SoriaBarreto, et al., 2016).

Consequently, the vision of pedagogy for entrepreneurship will be at the personal and collective level. Therefore, it will be essential to strengthen the competencies that allow them to understand the dynamics of society, as well as the economic movement of the context in which they operate.

In countries such as Finland, the United Kingdom, Colombia, Chile, etc., "education for entrepreneurship" is linked to the strengthening of the culture for entrepreneurship, whose aim is to develop various basic competencies in the labor and business field in formal and informal educational contexts. To this end, they foster favorable conditions to create and generate the sustainability of initiatives that favor personal, social and business development (Nugent, 2016). In addition, these countries have programs for entrepreneurship education, and pedagogical guides have been developed to guide teachers in incorporating entrepreneurship-related teaching into their pedagogical practices.

It is important to note, that the educational curriculum of such countries incorporates specific regulations, ensuring compliance with an education for entrepreneurship, illustrating teachers on what and how to teach, at the same time the recognition of the objectives to be achieved by each level of study and the evaluation of this (Nugent, 2016).

For this reason, characteristics that favor education for entrepreneurship are added, such as the scenarios in which students interact, where the work of the teacher or facilitator will be decisive to generate potentially entrepreneurial experiences. In the same way, in order to activate entrepreneurial ideas and initiatives, they are accompanied by attitudes and skills, with the purpose of guaranteeing and predicting future entrepreneurship.

In accordance with the previous paragraph, entrepreneurial competencies are differentiated as follows: The first, as initial and basic competencies, those that are given in basic education, which serve as a support and base, and the second the specialized entrepreneurial competencies, which are given in university education. 
In the findings of studies conducted in various educational centers at the primary level in Europe and Colombia, where education for entrepreneurship is taught, which are nowadays pedagogical referents in the achievement of entrepreneurial competencies, conclude that the entrepreneurial construction occurs in their life trajectory, but their true potential and development occurs in school and family (Gómez, et al.,2017; Hidalgo, et al., 2017).

We can affirm that entrepreneurial competencies are planned intentionally and their construction arises from the knowledge itself, from the knowledge and the experiential practice, i.e. through know-how. For this, it will be necessary to frame it within the educational, cultural, technological, environmental, etc. diversity.

Entrepreneurship education is not something new; it has already been addressed at international level through the European Commission, which differentiates between two concepts: education and business, distinguishing between business initiative and entrepreneurship, although both are interrelated.

In this sense, entrepreneurship alludes to the set of personal qualities and skills required to act in any context such as leadership, self-confidence, motivation, innovation, and resistance to failure, etc. while entrepreneurship corresponds to the generation of self-employment by making use of the aforementioned qualities (Alemany, et al., 2013).

With respect to learning entrepreneurship, it will be necessary to promote the following competencies from the early grades:

First, empowering autonomy, where the student will be able to recognize his or her limitations and potential, which will be the basis for building positive self-esteem, key to his or her integral development. In addition, there is a close relationship between self-esteem and success, since people with high self-esteem have a greater capacity to succeed and accept greater risks.

Secondly, leadership within the approach of education for entrepreneurship is intended that the student first develops his inner leadership and his decisions, in order to present it to others. Indeed, it will be necessary to develop communication skills so that they can effectively negotiate their points of view and affirm their interpersonal and intrapersonal relationships.
Thirdly, the development of innovation will allow them to move from an education based only on the transmission of content to one that integrates participation, human relations and attitudes. That is to say, to provide an adequate space to enhance their creativity not as a personal or isolated experience, but as a collective, real, palpable experience based on innovation.

Finally, fourthly, entrepreneurial skills are closely linked to the management of human and material resources, leading to decision making, understanding that it will be necessary to appropriate basic financial concepts for the creation of entrepreneurial projects and the management of the family economy in the future. In this way, it will allow students to put into practice the financial contents in real environments.

As far as learning to undertake is concerned, active methodologies based on projects should be applied, since the initiative and creativity of the teacher will not be enough; it will be essential to appropriate a methodology that stimulates the competence of learning to undertake, through cooperative work that guarantees its effectiveness (Alemany, et al., 2013; Paños, 2017).

Likewise, entrepreneurship education projects should contain a high dose of student intervention during implementation, development and evaluation, which will ensure commitment and thus guarantee the achievement of quality learning.

On the other hand, entrepreneurship projects allow students to get closer to real life, achieving good results in their learning. In short, they allow them to perceive more deeply the context in which they develop, leading them to identify the needs and opportunities to be transformed.

It is also worth mentioning the transferability within the learning to undertake, which will be substantial, since it is considered as a test to nurture their vision as adults at a personal and professional level. At the same time, they will be accompanied at all times by their teachers, with the purpose of producing important fruits in their learning on a small scale, all of which will lead students to creatively transfer what they have learned to diverse situations and new experiences.

Continuing with the analysis, the systematic spiral training is another essential feature within the entrepreneurial knowledge that allows 


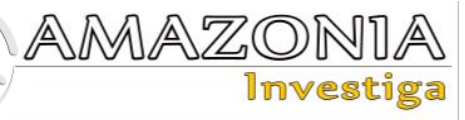

teaching the student to become an entrepreneur from a very early age. Hence, it will stimulate entrepreneurial skills, being important to plan initiatives from basic education, the role of the teacher with the appropriate school curriculum and the performance of students of different ages.

So, if we want to optimize learning entrepreneurship, we will have to leave the classroom and bring the wisdom of the outside world, through various experiences such as guided tours, productive experiences, family experiences, etc. However, first we will have to break down the walls of the school with the intention of achieving direct contact with the real and daily life of the local world.

In short, learning to be an entrepreneur seeks to prepare students for an adult life by committing to forge fair and caring people, not only to make them autonomous with initiative but also as a social investment in the future.

In addition, to achieve the fifth pillar "learning to undertake", the committed participation of teachers, students and parents will be fundamental.

The European Commission (2014) highlights the passion that entrepreneurial teachers contain for teaching. They are charismatic, open, confident, flexible and extremely responsible. In addition, they practice active listening and take advantage of ideas to transform them into actions.

At the same time, they constantly seek to bridge the gap between education and economics, through the experimentation of real-life cases. At the same time, their work plan is flexible and interdisciplinary, highlighting group interaction, relating the classroom to a conflict scenario, encouraging the exchange of opinions, answers, solutions, reflections, etc.

In this sense, an entrepreneurial teacher is not much of a lecturer, but much of a trainer, being an active participant in the personal construction of competencies in his students. Thus, entrepreneurial learning during initial training should incorporate the development of skills, methods of innovation and entrepreneurship, inspiring students.

For this reason, future teachers must be role models for their students, directing them to develop as active members of a society of constant change and great challenges. Therefore, it is necessary to propose an itinerary with the purpose that future teachers demonstrate to be an example for the whole society.

On the other hand, Arruti (2016) states the urgency of implementing various relevant educational actions capable of generating entrepreneurial skills among primary school students.

In addition to this, Del solar (2010) indicates that entrepreneurship is a challenge to the integrity of young people, requiring the strengthening of their ability to overcome adversities, being especially important their personal development, personal skills, and the ability to develop their own skills.

Adversities, being especially important their personal development, thinking, attitudinal and value skills. Therefore, the student becomes the protagonist of the whole process of teaching and learning.

Accordingly, an education at an early age will define the foundations that will govern the conduct and good work of students. Consequently, an entrepreneurial culture at an early age will positively influence their attitudes and the development of their entrepreneurial skills in the long term (Rodríguez, et al., 2014; Sánchez García, et al., 2017).

In addition, within the learning to undertake, the entrepreneurship projects will have to count on the complicity of the parents, rescuing their experiences, thus giving them an added value to the preparation of their children. In this sense, family expectations will positively influence the success of the ideal school.

In fact, an enterprising student should through sufficient motivation be able to overcome the objectives proposed during the session, having the predisposition to transform learning into meaningful. In addition, it is important to mention that the enterprising student, not only bases his training on theoretical concepts, but also on attitudes to be able to understand, explain and act appropriately.

In addition to this we can rescue some countries that have successfully implemented entrepreneurship education, such is the case of Finland, Spain, Colombia, etc.

Definitely the education system in Finland has caught the attention of the whole world, thanks to its great international success in the OECD's PISA evaluation, demonstrating high educational 
productivity. Likewise, the European Union considers the country as the best in terms of education. (Leinonen, Partanen, \& Palviainen, 2004).

At present, Finland is in a moment of development of various jobs and companies called brain sectors, which complement the traditional entrepreneurship. Thus, their students live a real and specialized experience within what the country requires, establishing an education with an entrepreneurial spirit.

In this sense, the use of didactic materials within the sessions is of great importance for the development of entrepreneurial skills. Likewise, companies must be familiar with this thinking, with a view to instilling an entrepreneurial and innovative education within the educational system.

Consequently, the purpose of education in Finland is to be able to export its educational system to the rest of the world, offering diverse solutions for diverse clients and realities.

To achieve the quality of education that Finland has imposed on the world, they have required a lot of national cooperation. All universities responsible for teacher education established and share a national network of educational sciences and teacher education. Thus, its main objective is to establish a program of interaction and exchange of teacher knowledge, which seeks consensus on the components and structure of teacher education. Despite its autonomy, each university starts from this profile to establish the basis of its own curriculum (Valencic \& Vogrinc, 2011).

As a result, teaching careers in Finland are highly competitive and highly prestigious for the nation. Only ten percent of applicants are accepted for further teaching careers. Consideration is given in the teacher education curriculum to the choice of one academic discipline and an accompanying optional discipline. As well as research development on methodological studies. Pedagogical studies including teaching practice. Communicative and language development are mandatory. In turn, since 2015 a personal plan study was implemented for effective personal development.

Similarly, the main objective of pedagogical studies in Finland is to create opportunities for learning and pedagogical interaction to develop their own teaching skills. Thus, students should achieve collaborative learning with all actors in the teaching-learning process.

Finally, Tarhan, Caraman, Kemppinen \& Aerila (2019), highlight that Finnish education reemerged thanks to the positive relationship between social educational policy and the idea about social justice. It is so that the state having as its main objective that the citizenship is provided with an opportunity for prosperity of life.

Therefore, the state inspectors played a fundamental role in monitoring that the schools strictly follow what is established by the educational system and thus regain the trust and respect of their educators. Thus, preparing their students for the challenges that the 21 st century demands.

In the same way, Guarnizo, et al., (2017), state that the Colombian state, since 2006, has been concerned about implementing an education that allows children in primary and secondary education to prepare them to face the productive reality through the development of competencies related to entrepreneurship. It can be pointed out that it seeks an education that transcends the economic and encompasses the personal, family, professional and social progress of the student.

In fact, such education in entrepreneurship is stipulated by law, establishing it as an educational policy, articulating it throughout the entire schooling, from the initial, basic and middle levels. To this end, it establishes that educational institutions must select a learning area to include entrepreneurship and business creation as part of the national curriculum. In this sense, the selected area should be complemented with contextualized activities, thus allowing to visualize the work of students in the projects and fairs they participate in, linked to entrepreneurship and entrepreneurship (Guarnizo, et al., 2017).

In turn, in compliance with the provisions of this law, educational institutions designed a new chair or subject of education for entrepreneurship, providing it throughout the school process, with a projection to the creation of enterprises.

In addition, in 2012, after a study and analysis of the definitions of entrepreneurship and entrepreneurship, the Ministry of Education in Colombia published a methodological guide, responsibly assuming the leadership for the implementation of education for 


\section{AMAZONIA \\ ]กvestiga}

entrepreneurship. Thus, it seeks the resignification, which allows the school curriculum to offer an education for entrepreneurship, articulating it to the institutional strategic objectives and the development of competencies, seeking the integral development of students. Thus, it encourages the development of projects that promote the entrepreneurial culture without neglecting the entrepreneurial attitude.

Entrepreneurial culture refers to the set of customs, ideologies, values, norms, etc., which are generated from collective interrelationships establishing an identity with respect to others. Entrepreneurial attitudes refer to the personal predisposition to generate and transform innovative ideas favoring the growth and consolidation of the life project.

In short, this information can be compared and asserted by observing the efforts of countries of the European Union who are committed to an education that encourages the development of basic competencies, including the development of initiative and entrepreneurship, based on the strengthening of attitudes conducive to generating entrepreneurship, such as: initiative, risk-taking, management of uncertainty, etc., all with the intention that they can face the productive challenges of today's society (Guarnizo, et al., 2017).

Something similar happens in Spain, where education for entrepreneurship is deepened through the formation of different attitudes that dynamize entrepreneurial behavior, implementing it throughout the educational process from primary to secondary school, thus generating an optimal culture of school entrepreneurship.

For a better understanding, it is essential to implement a global educational policy that aims at training for entrepreneurship with a projection to integral development and the construction of a life project in students, beyond providing solutions to current problems.

\section{Conclusions}

1. In order to be able to direct us to a path of entrepreneurship, taking into consideration the four pillars of education, we seek a transformation in the ideas of the students, towards actions that generate personal development. In this sense, it is possible to demonstrate that students are capable of facing the risk of failure, through the development of social entrepreneurship competencies. These are the ones that will allow an integral development of individuals at any stage of their lives. Therefore, the entrepreneurial student is an agent of change, having the ability to identify opportunities where others cannot see them. This competence can be learned or in some cases improved, through a variety of real situations in which the student will develop from basic education to higher education, forming their cognitive structure to provide solutions to contextual problems and future initiatives. In addition, entrepreneurial competencies are directed towards attitudes, knowledge and skills that strengthen and transform their living conditions.

2. One of the key points of this article is that traditional teaching should be transformed from the perspective of the four pillars of education. This will contribute to the development of both entrepreneurial skills and attitudes. Thus, by mentioning knowing how to be, we are looking for people's proactivity, creativity, self-efficacy and selfconfidence. They must be autonomous, tolerant of ambiguity and frustration. By highlighting knowledge, we look at the world from its socioeconomic interaction in favor of citizens, handling various tools that evaluate the opportunities and the development of the entrepreneur. Consequently, knowing how to do leads to the solution of various problems, implementing effective communication and teamwork.

3. The importance of looking at entrepreneurship through education lies in the fact that entrepreneurial students are visionaries, leading their personal lives and understanding social dynamism. In this way, entrepreneurship education provides knowledge, skills and attitudes that will allow them to become entrepreneurs. Thus, education for entrepreneurship will take place in the personal and collective sphere, and it is essential to develop the competencies that will allow them to provide solutions to individual and social problems. Therefore, the teacher's work at this stage is decisive to generate those entrepreneurial skills that students require so much and that should be framed in their educational, cultural, social and environmental activities.

4. Within the roles of education to achieve entrepreneurship and reach the so desired fifth pillar "learning to undertake", the active participation of parents will be required, since rescuing their experiences will 
strengthen the preparation of their children and thus influence the success and construction of an ideal school. Definitely, the enterprising student, through the necessary motivation, will have the capacity to overcome any proposed obstacle, having the predisposition to generate significant learning. Consequently, an enterprising student is not only theoretical, but also develops attitudes that are able to understand, explain and act appropriately in their social environment.

5. In recent years, the success of several countries, such as Finland, Spain, Colombia, etc., has been observed, achieving a globally recognized entrepreneurial education system. Likewise, they have created and implemented a variety of didactic tools, strengthening the competencies of social entrepreneurship as a transversal line in the school curriculum. This is a great example of disciplined work and mutual support for the benefit of all involved, and therefore the global community.

6. This is why the experts of the global monitoring of entrepreneurship, within the global education policy, when analyzing the ecosystems and favorable conditions for entrepreneurship to take place, suggest integrating it as a cross-cutting competency in the educational curriculum. Accordingly, they suggest training the entrepreneurial spirit throughout schooling, from basic education to higher education. In addition, they suggest prioritizing the use of methodological tools, through active pedagogy, to promote the development of social entrepreneurship competencies.

\section{Bibliographic references}

Alemany, L., Marina, J., Pérez, J., Pellicer, C., Álvarez, B., \& Torrejón, J. (2013). Aprender a emprender ¿Cómo educar el talento emprendedor? España: aulaPlaneta

Arbeláez-Campillo, D. F., Dudareva, M. A., \& Rojas-Bahamón, M. J. (2019). Las pandemias como factor perturbador del orden geopolítico en el mundo globalizado. Cuestiones Políticas, 36(63), 134-150.

Arruti, A. (2016). El desarrollo del perfil del teacherpreneur o profesor emprendedor en el currículum del grado de educación primaria: ¿Un concepto de moda o una realidad? Contextos educativos: Revista de educación, 9, 177-194

Arruti, A., \& Castro, J. P. (2019). Análisis de las menciones del grado en Educación Primaria desde la perspectiva de la competencia emprendedora. Revista Complutense de Educación, 30(1), 17.

Bula, H.O. (2012). Performance of women entrepreneurs in small scale enterprises (SSEs): Marital and family characteristics. European Journal of Business and Management, 4(7), 85-99.

Cabana-Villca, R., Cortes-Castillo, I., Plaza-Pasten, D., Castillo-Vergara, M., \& Alvarez-Marin, A. (2013). Análisis de las capacidades emprendedoras potenciales y efectivas en alumnos de centros de educación superior. Journal of technology management \& innovation, 8(1), 65-75.

Consejo Nacional de Educación (2020). Proyecto Educativo Nacional al 2036. Lima - Perú. https://www.cne.gob.pe/uploads/publicacion es/2020/proyecto-educativo-nacional-al2036.pdf

Comisión Europea, (2014). Educación en emprendimiento. Guía del educador. Bruselas. https://docer.com.ar/doc/nss050v

Crisólogo, A. (2008). Diccionario pedagógico, edición actualizada. De acuerdo con los nuevos conceptos de las ciencias pedagógicas. Abedul: Lima-Perú. https://isbn.cloud/9789972775079/diccionari o-pedagogico/

Del Solar, S. (2010). Emprendedores en el aula. Guía para la Formación en Valores y Habilidades Sociales de Docentes y Jóvenes Emprendedores. FUNDAR Región. Recuperado de https://www.teduca.cl/descargas/pdfs_portal/emprendimie nto/EmprendedoresWEB1.pdf

Gómez, L., Marina, L., Hernández, T., Mejía, D., Heilbron, J., Gallego, J., Senior, D. (2017). Competencias emprendedoras en básica primaria: Hacia una educación para el emprendimiento. Pensamiento \& Gestión, (43) Retrieved from https://www.redalyc.org/pdf/646/646535140 07.pdf

Guarnizo, C., Velásquez, J., Jiménez, C., Álzate, B. (2017). Educación para el emprendimiento: análisis y aportes a la política pública de educación en Colombia desde la sistematización de experiencias en instituciones de educación básica y media. Revista complutense de educación, 30(1), 225-243.

http://dx.doi.org/10.5209/RCED.57165

Hidalgo, M. (2000). Gestión Pedagógica. Aplicable a Educación Inicial, Primaria, Secundaria, Bachillerato y Superior. Lima: INADEP

https://minedu.gob.pe/normatividad/plan_ins titucional/poa00/plan_institucional2000.pdf 


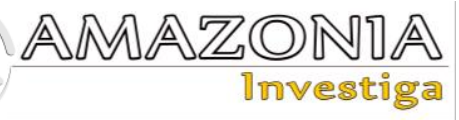

Hidalgo, L., Trelles, I., Castro, A., \& Loor, B. (2017). Formación en emprendimiento en el Ecuador. Pertinencia y fundamentación epistemológica. Revista espacios, 39 (7), 12. http://www.revistaespacios.com/a18v39n07/ a18v39n07p12.pdf

Lederman, D., Messina, J., Pienknagura, S., \& Rigolini, J. (2014). El emprendimiento en América latina. Muchas empresas y poca innovación. Washington: EEUU: Banco mundial sobre América latín y el caribe.

https://www.worldbank.org/content/dam/Wo rldbank/document/LAC/EmprendimientoAm ricaLatina_resumen.pdf

Leinonen, N., Partanen, J. \& Palviainen, P. (2004). Team Academy: a true story of a community that learns by doing. PSkustannus. ISBN 9524511037

López, E. (2016). En torno al concepto de competencia: Un análisis de fuentes Profesorado. Revista de Currículum y Formación de Profesorado, (20), 311-322. Universidad de Granada, España

Martínez, F. \& Carmona, G. (2009). Aproximación al concepto de "competencias emprendedoras": Valor social e implicaciones educativas. REICE. Revista Iberoamericana Sobre Calidad, Eficacia y Cambio en Educación, (7), 82-98.

Mayor, F. (1998). La educación a las puertas del tercer milenio: Discurso con motivo del Congreso Intercontinental de Educación. Paris. https://silo.tips/download/laeducacion-a-las-puertas-del-tercer-milenio

Ministerio de educación (2017). Currículum Nacional de la Educación Básica. Lima- Perú. http://www.minedu.gob.pe/curriculo/

OECD (2016). Perspectivas económicas de América Latina 2017: Juventud, competencias y emprendimiento. Paris: OECD Publishing.

OECD (2019). El trabajo de la OCDE sobre educación y competencias. Francia. https://www.oecd.org/education/El-trabajode-la-ocde-sobre-educacion-ycompetencias.pdf

Paños Castro, J. (2017). Educación emprendedora y metodologías activas para su fomento. Revista Electrónica Interuniversitaria de Formación del Profesorado, $20 \quad$ (3), 33-48. http://dx.doi.org/10.6018/reifop.20.3.272221

Rodríguez, J. Dalmau, J. Pérez-Aradros, B. Gargallo, E. Rodríguez, G. (2014). Educar para emprender. Guía didáctica de educación emprendedora en primaria. Universidad de la Rioja.

Sáenz, N. \& López, A. (2015). Las competencias de emprendimiento social: Aproximación a través de programas de formación universitaria en Iberoamérica. REVESCO: Revista De Estudios Cooperativos, (119), 159-182. Recuperado

Sánchez, J. (2013). The impact of an Entrepreneurship Education Program on entrepreneurial competencies and Intention. Journal of Small Business Management, (51), 447-465.

Sánchez García, J. C., Ward, A., Hernández, B., \& Florez, J. L. (2017). Educación emprendedora: Estado del arte. Propósitos y Representaciones, 5(2), 401-473.

Shapero, A., \& Sokol, L. (1982). The social dimensions of entrepreneurship. Encyclopedia of entrepreneurship. University of Illinois at Urbana-Champaign's Academy for Entrepreneurial Leadership, pp. 72-90.

Seria, J., Alzamora, J., Guerrero, C., Borda, A., \& Morales, O. (2020). Global Entrepreneurship monitor. Lima: ESAN.

Schumpeter, J. (1934). The Theory of Economic Development. Cambridge: Harvard University Press.

Soria-Barreto, K., Zuniga-Jara, S., \& Ruiz-Campo, S. (2016). Educación e intención emprendedora en estudiantes universitarios: Un caso de estudio. Formación universitaria, 9(1), 25-34.

Taatila, V. (2010). Learning entrepreneurship in higher education. Education Training, (52) 48-61.

Tarhan, H. Caraman, A. Kemppinen, L. \& Aerila, J. (2019). Understanding Teacher evolution in Finland: A professional Development Framework. Australian Journal of teacher Education, 44(4)

Timmons, J.A. (1989). The entrepreneurial mind, andover, mass. Brick House Publishing.

Tobón, S. (2010). Formación integral y competencias. Pensamiento complejo, currículo, didáctica y evaluación. Bogotá Colombia: ECOE Ediciones.

Unesco (2016). Desglosar el objetivo de desarrollo sostenible 4 Educación 2030. https://www.buenosaires.iiep.unesco.org/site s/default/files/archivos/ODS4_0.pdf

Valencic Z.M. \& Vogrinc, J (2011) European Dimensions of Teacher education Similarities and Differences. SloveniaLjubljana: The National School of Leadership and education. 